\title{
Rapid response of a deep-sea benthic community to POM enrichment: an in situ experimental study
}

\author{
U. Witte ${ }^{1, *}$, N. Aberle ${ }^{1,2}$, M. Sand ${ }^{1}$, F. Wenzhöfer ${ }^{1,3}$ \\ ${ }^{1}$ Max Planck Institute for Marine Microbiology, Celsiusstr. 1, 28359 Bremen, Germany \\ ${ }^{2}$ Present address: Max Planck Institute for Limnology, PO Box 165, 24302 Plön, Germany \\ ${ }^{3}$ Present address: Marine Biological Laboratory, University of Copenhagen, Strandpromenaden 5, 3000 Helsingør, Denmark
}

\begin{abstract}
A series of in situ enrichment experiments was carried out at $1265 \mathrm{~m}$ water depth in the Sognefjord on the west coast of Norway in order to follow the short-term fate of freshly settled phytodetritus in a deep-sea sediment. For all experiments, a deep-sea benthic chamber lander system was used. In the lander chambers, a settling spring bloom was simulated by the injection of $0.2 \mathrm{~g}$ of freeze-dried Thalassiosira rotula, an equivalent of $1 \mathrm{~g}$ organic $\mathrm{C} \mathrm{m}^{-2}$. The algae were $98 \%$ ${ }^{13} \mathrm{C}$-labeled, thus enabling us to follow the processing of the carbon by bacteria and macrofauna. Experiment duration varied from $8 \mathrm{~h}$ to $3 \mathrm{~d}$. The total oxygen consumption of the sediments increased by approximately $25 \%$ due to particulate organic matter (POM) enrichment. Macrofauna organisms became immediately labeled with ${ }^{13} \mathrm{C}$. After $3 \mathrm{~d}, 100 \%$ of the individuals sampled down to $10 \mathrm{~cm}$ sediment depth had taken up ${ }^{13} \mathrm{C}$ from the phytodetritus added. Bacterial uptake of the tracer was fast too, and even bacteria in deeper sediment layers had incorporated the fresh material within $3 \mathrm{~d}$. Our study documents the rapid downward mixing of labile organic matter and the importance of macrofauna for this process. We present the first evidence for the immediate breakdown and incorporation of POM by bacteria even in deep sediment layers. Surprisingly, the initial processing of carbon was dominated by macrofauna, although the group comprises $<5 \%$ of the benthic biomass. Altogether, approximately $5 \%$ of the carbon added had been processed within $3 \mathrm{~d}$, with the majority being released from the sediment as $\mathrm{CO}_{2}$. Due to the good comparability of our study site with midslope settings at continental margins, in general, we propose that the processes we observed are widespread at continental margins and are significant for the biogeochemical cycling of particulate matter on the slope.
\end{abstract}

KEY WORDS: Continental slope $\cdot$ Deep sea $\cdot$ Pulse-chase experiment $\cdot \delta^{13} \mathrm{C} \cdot$ Benthic carbon remineralization $\cdot$ Macrofauna $\cdot$ Bacteria $\cdot \mathrm{SCOC}$

\section{INTRODUCTION}

Benthic communities in continental-slope and deepsea sediments depend on the export of particulate matter from productive surface waters for food. This export flux is directly linked to surface water dynamics and is by no means constant in time. At continental margins, particle export from the shelves often leads to high rates of particle deposition that stimulate an enhanced biogeochemical degradation of organic matter in these sediments. Although continental margins comprise only $11 \%$ of the surface area of the world oceans, more than $80 \%$ of the global benthic mineralization is thought to take place here (Jörgensen 1983, Middelburg et al. 1997, Lohse et al. 1998).

The rapid deposition, accumulation and turnover of relatively fresh phytodetritus on the deep ocean floor is well documented by now (e.g. Billett et al. 1983, Lampitt 1985, Thiel et al. 1989, Hecker 1990), and a variety of numerical and functional responses of the benthos to this episodical, often seasonal, food input has been described-ranging from bacteria (e.g. Lochte \& Turley 1988) and protozoa (e.g. Linke 1992, Gooday et al. 1993, Linke et al. 1995) to megafauna 
(e.g. Tyler 1988, Tyler et al. 1990, Witte 1996, Lauermann et al. 1997). Benthic organisms feed on, process and redistribute the arriving organic material, incorporate it into their biomass and cause mixing and burial by means of locomotion, feeding, etc. Through these activities, benthic organisms play an important role in the early diagenesis of organic material arriving at the seafloor. For the South Atlantic, Wenzhöfer \& Glud (2002) calculated that up to $70 \%$ of the total oxygen consumption of sediments was mediated by benthic fauna.

However, the existing data are very scattered, and comprehensive studies of the response of a benthic community to a sedimentation event are scarce. For the sediment community oxygen consumption (SCOC), for example, usually considered to be the most reliable measure of total benthic carbon remineralization (BCR) rates in deep-sea areas exposed to well-oxygenated bottom waters, the question of whether BCR varies in relation to sedimentation events is still somewhat equivocal. There are as many data in favour of this hypothesis as against it (e.g. Smith \& Baldwin 1984, Pfannkuche 1993, Drazen et al. 1998, Witte \& Pfannkuche 2000, but see also Sayles et al. 1994, Pfannkuche et al. 1999). In addition, even when temporal changes of SCOC are evident, it still remains difficult to pinpoint the steering factors triggering the benthic response. Neither the speed and amplitude of this response nor the pathways and degradation rates of organic carbon at the deep-sea floor can as yet be predicted. The descriptive approaches to this question have often been hampered by logistic difficulties and the unpredictability of seasonal sedimentation events (Pfannkuche et al. 1999). To overcome these difficulties, within the BIGSET II program we chose an in situ experimental approach: a series of in situ enrichment experiments with stable isotope tracers were performed to clarify the short-term fate of fresh phytodetritus arriving at deep-sea sediments. In recent years, stable isotope techniques have been applied successfully for food-web studies (e.g. Fry 1988). In a very elegant approach, Middelburg et al. (2000) followed the fate of intertidal microphytobenthos carbon by spraying ${ }^{13} \mathrm{C}$-labeled bicarbonate solution onto tidal flat sediments and tracing its pathway through the benthic community. In a first, short-term in situ study in deep-sea sediments, Moodley et al. (2002) pointed out the importance of Bacteria and Foraminifera in the initial processing of organic carbon. Bioturbation studies on the continental slope off Cape Hatteras (850 m) have confirmed the importance of macrofauna for the processing of organic carbon arriving at the deepocean floor: Blair et al. (1996) and Levin et al. (1997) demonstrated the rapid downward mixing of freshly deposited ${ }^{13} \mathrm{C}$-labeled algal material by maldanid poly- chaetes to depths of 4 to $13 \mathrm{~cm}$ on time scales of 1 or $2 \mathrm{~d}$.

Here, the short-term response of a deep-sea benthic community to a settling food pulse is investigated. We present data from 4 in situ enrichment experiments carried out with a benthic chamber lander off the west coast of Norway (1265 m). A food pulse, consisting of diatoms labeled with ${ }^{13} \mathrm{C}$, was simulated in the chambers and uptake or incorporation of the algal carbon by the different functional benthic groups of organisms was followed. Particular attention was paid to macrofauna, because large organims can be keystone players for the rapid subduction of organic matter into the sediment (Levin et al. 1997). Changes in the total oxygen uptake (TOU) of the sediment were monitored as a bulk measure of changes in total BCR rates, and bacteria were monitored as they are regarded as the primary agents of organic matter degradation in deep-sea sediments.

\section{MATERIALS AND METHODS}

The experiments were carried out during Cruise 128 with RV 'Heincke' (14 to 26 February 2000) at $1265 \mathrm{~m}$ water depth in the Sognefjord on the west coast of Norway. With a maximum depth of $1300 \mathrm{~m}$, the Sognefjord is the world's deepest fjord, with an extension of $180 \mathrm{~km}$ and a sill depth of $200 \mathrm{~m}$ (Poremba \& Jeskulke 1995). Bottom water temperature during the expedition was $7^{\circ} \mathrm{C}$ and bottom water oxygen concentration was 195 to $225 \mu \mathrm{mol} \mathrm{l^{-1 }}$.

A deep-sea benthic chamber lander (for a detailed description of the lander see Witte \& Pfannkuche 2000) equipped with 3 benthic chambers (0.04 $\mathrm{m}^{2}$ each) was used in all experiments. Each chamber lid was equipped with an injection unit for the addition of the labeled particulate organic matter (POM) at the beginning of each incubation, approximately $1 \mathrm{~h}$ after insertion of the lander chambers into the sediment. Four lander deployments of 8 to $72 \mathrm{~h}$ duration were carried out (Table 1). In order to simulate the sedimentation of an early spring bloom, $0.2 \mathrm{~g}$ of freeze-dried ${ }^{13} \mathrm{C}$ labeled Thalassiosira rotula, equivalent to $1 \mathrm{~g}$ organic $\mathrm{C} \mathrm{m}^{-2}$, was inserted into 2 chambers; the third served as control. The phytodetritus was distributed by a stirrer within the chamber in order to achieve homogeneous sedimentation. Each chamber was equipped with a syringe water sampler that took 7 water samples of $50 \mathrm{ml}$ at preprogrammed intervals during the incubation as well as $2 \mathrm{O}_{2}$ optodes that continuously recorded the $\mathrm{O}_{2}$ concentration in the chamber water. Incubation times are calculated from first-to-last syringe sampling. SCOC was determined by Winkler titration of syringe water samples (2 replicates) and 2 oxygen 
Table 1. Lander deployments in Sognefjord (Norway) during Cruise 128 with RV 'Heincke' in 2000

\begin{tabular}{|c|c|c|c|c|c|}
\hline Stn & Lander & Deployment & $\begin{array}{c}\text { Incubation } \\
\text { time }\end{array}$ & Location & $\begin{array}{c}\text { Depth } \\
\text { (m) }\end{array}$ \\
\hline 8 & FFR 1 & $18-20$ Feb & $1.5 \mathrm{~d}$ & $61^{\circ} 08.51^{\prime} \mathrm{N}, 06^{\circ} 01.43^{\prime} \mathrm{E}$ & 1258 \\
\hline 12 & FFR 2 & $19-22$ Feb & $3 \mathrm{~d}$ & $61^{\circ} 09.02^{\prime} \mathrm{N}, 05^{\circ} 57.87^{\prime} \mathrm{E}$ & 1269 \\
\hline 18 & FFR 3 & 20-22 Feb & $1.5 \mathrm{~d}$ & $61^{\circ} 08.52^{\prime} \mathrm{N}, 06^{\circ} 01.22^{\prime} \mathrm{E}$ & 1261 \\
\hline 29 & FFR 4 & 22-23 Feb & $8 \mathrm{~h}$ & $61^{\circ} 08.54^{\prime} \mathrm{N}, 06^{\circ} 01.26^{\prime} \mathrm{E}$ & 1255 \\
\hline
\end{tabular}

Six chambers were sampled in total for analysis of macrofauna. Sediment was sliced in layers of $0-1,1-2,2-5$ and $5-10 \mathrm{~cm}$ and sieved carefully on a $250 \mu \mathrm{m}$ sieve. The organisms were stored deep frozen until sorting under a stereo microscope in the home laboratory. After taxonomic identification, all specimens were freeze-dried in vacuo for the subsequent determination of ${ }^{12} \mathrm{C}:{ }^{13} \mathrm{C}$ ratios. In most cases, single organisms were measured, but occasionally it was necessary to pool specimens within a certain taxon in order to achieve sufficient biomass for the determination of ${ }^{12} \mathrm{C}:{ }^{13} \mathrm{C}$ ratios. Isotopic composition of macrofauna organisms were measured on an ANCA 20-20 (Europe Scientific) isotope ratio mass spectrometer (IRMS). Biomass of macrofauna was determined as dry weight $(\mathrm{dw})$ in $\mathrm{mg}$ per square meter of the freeze-dried material prior to the measurements of ${ }^{12} \mathrm{C}:{ }^{13} \mathrm{C}$ ratios and converted into organic $\mathrm{C}$, applying taxon-specific conversion factors as described in Witte (2000).

From the remaining 6 chambers, samples for the determination of bacterial biomass and incorporation of ${ }^{13} \mathrm{C}$ tracer into bacterial phospholipid-derived fatty acids (PLFA) were taken. Sampling was carried out in 3 sediment horizons: $0-2,2-5$ and $5-10 \mathrm{~cm}$. As even small-scale sediment topography results in an uneven distribution of labeled POM on the sediment surface, sediment from each sampling horizon was homogenized carefully. Then, subsamples were taken with cut-off syringes of $2.1 \mathrm{~cm}$ diameter for phospholipid (PL) analysis (3 subsamples per chamber). Quantification of PL was carried out after a modification of the method of Findlay et al. (1989) according to Boetius et al. (2000). The mean PL concentration $\mathrm{cm}^{-3}$ sediment was calculated from the measurement of 3 replicate subsamples. PL concentrations were converted into total microbial biomass with a conversion factor of $100 \mu \mathrm{mol} \mathrm{PL} \mathrm{g}{ }^{-1} \mathrm{C}$ (Dobbs \& Findlay 1993).

The lipid extract was fractionated on silicic acid into different polarity classes by sequential eluting with chloroform, acetone and methanol. The methanol fraction was derivatized using mild alkaline methanolysis to yield fatty acid methylesters (FAME) in accordance with Boschker et al. (1999) and Middelburg et al. (2000). FAME concentrations were determined by gas chromatography-flame ionisation detection (GC-FID). Carbon isotope ratios as determined by GC-IRMS were corrected by using a mass balance for the 1 carbon atom in the methyl group added during derivatization. The carbon isotope ratios are expressed in the delta notation $\left(\delta^{13} \mathrm{C}\right)$ relative to Vienna PDB: $\delta^{13} \mathrm{C}(\%)=$ $\left[\left({ }^{13} \mathrm{C}:{ }^{12} \mathrm{C}\right)_{\text {sample }} /\left({ }^{13} \mathrm{C}:{ }^{12} \mathrm{C}\right)_{\text {reference }}-1\right] \times 1000$. The methanol used for derivatization had a ratio of $\delta^{13} \mathrm{C}=-37.6 \%$. mean C:N ratio was 13 . 
The incorporation of ${ }^{13} \mathrm{C}$ label by the macrofauna organisms is expressed as specific uptake or excess ${ }^{13} \mathrm{C}$ above background (i.e. $\Delta \delta^{13} \mathrm{C}=\delta^{13} \mathrm{C}_{\text {sample }}-$ $\delta^{13} \mathrm{C}_{\text {background }}$ ) or total uptake $(I)$ in $\mathrm{mg}{ }^{13} \mathrm{C} \mathrm{m}^{-2}$. For macrofauna, $I$ was calculated as the product of excess ${ }^{13} \mathrm{C}$ and biomass. For bacteria, I was calculated after Middelburg et al. (2000) from label incorporation into bacterial PLFA (c15:0i, c16:0i, c17:0i, cy17:0, c19:0i) as $I_{\text {bact }}=\Sigma I_{\text {PLFAbact }} /(a \times b)$, where $a$ is the average PLFA concentration in bacteria of $0.056 \mathrm{~g}$ of carbon PLFA g ${ }^{-1}$ $C$ biomass (Brinch-Iversen \& King 1990) and $b$ is the average fraction-specific bacterial PLFA encountered in sediments dominated by bacteria $(0.20$; calculated after Middelburg et al. 2000, Moodley et al. 2002 and literature therein).

\section{RESULTS}

\section{Sediment community oxygen consumption}

OPD in the deep Sognefjord was $16.8 \pm 1.7 \mathrm{~mm}$ (mean $\pm \mathrm{SD}$ ). The DOU of the sediments was $1.44 \pm$ $0.24 \mathrm{mmol} \mathrm{O}_{2} \mathrm{~m}^{-2} \mathrm{~d}^{-1}$ (Table 2). The SCOC (also termed TOU), as determined by the chamber incubation, was twice as high $\left(3.6 \mathrm{mmol} \mathrm{O}_{2} \mathrm{~m}^{-2} \mathrm{~d}^{-1}\right)$. If it is taken into account that laboratory measurements tend

Table 2. Diffusive oxygen uptake (DOU) and oxygen penetration depth (OPD) in the deep Sognefjord

\begin{tabular}{|lcc|}
\hline Sensor & DOU $\left(\mathrm{mmol} \mathrm{O}_{2} \mathrm{~m}^{-2} \mathrm{~d}^{-1}\right)$ & OPD $(\mathrm{mm})$ \\
\hline 1 & 1.59 & 17.2 \\
2 & 1.56 & 18.3 \\
3 & 1.16 & 15.0 \\
Mean $\pm \mathrm{SD}$ & $1.44 \pm 0.24$ & $16.8 \pm 1.7$ \\
\hline
\end{tabular}

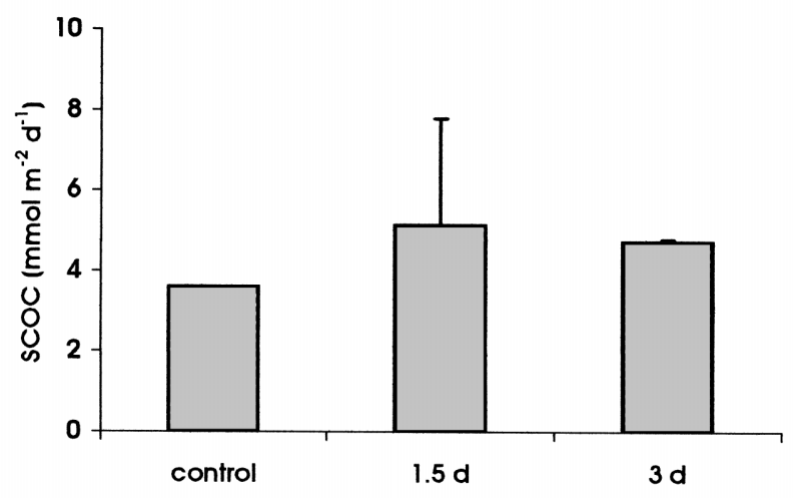

Fig. 1. Changes in mean sediment community oxygen consumption (SCOC) due to POM enrichment. Error bars represent $+\mathrm{SD}$ to overestimate DOU, benthos-mediated oxygen uptake (BMU, i.e. the difference between TOU and DOU, which comprises the metabolism of the animals itself as well as the activity stimulated by the organisms) amounts to at least $50 \%$, highlighting the importance of large organisms for carbon remineralization in these sediments. Changes in the SCOC due to the enrichment with POM are depicted in Fig. 1. There was a slight (approx. 25\%) but significant increase in SCOC after $3 \mathrm{~d}$. SCOC after $1.5 \mathrm{~d}$, however, was more heterogeneous. As 2 deployments of 1.5 d duration were carried out, and the very high SCOC measurements that cause the high standard deviation both originate from the same deployment (FFR 3, Table 1), these results probably represent the scale of lateral heterogeneity in SCOC occurring at the study site.

\section{Macrofauna}

Macrofauna abundance and biomass in the deep Sognefjord were $2930 \pm 680$ ind. $\mathrm{m}^{-2}$ and $490 \pm 184 \mathrm{mg}$
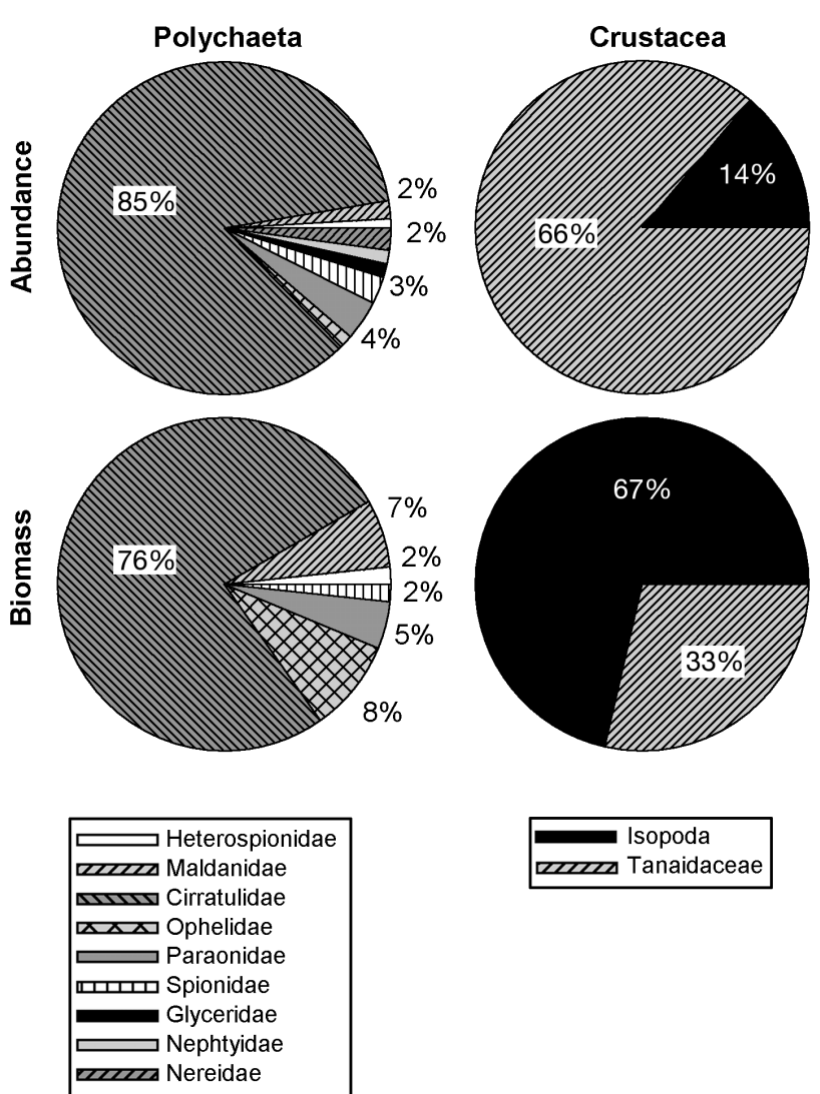

Isopoda Tanaidaceae

Fig. 2. Relative abundance and biomass of Polychaeta and Crustacea in the deep Sognefjord. Note that $18 \%$ of polychaetes could not be identified to family level due to breakage because of the unavoidable freezing of the samples prior to sorting 

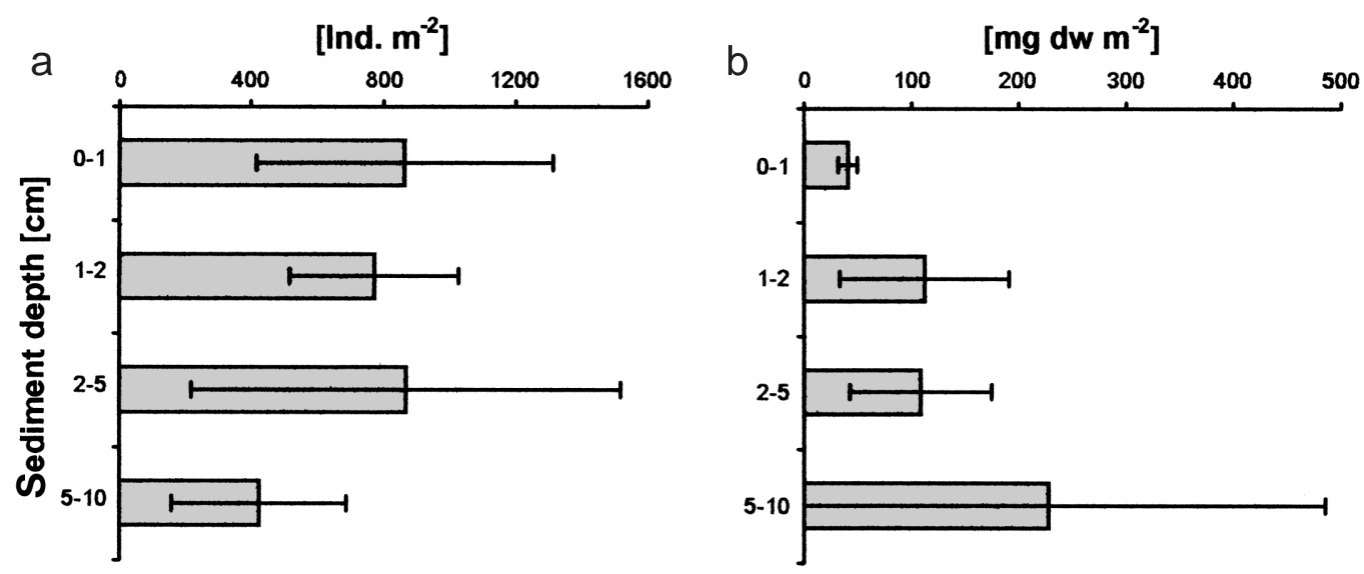

Fig. 3. Vertical distribution of mean (a) abundance and (b) biomass of macrofauna within the sediment. Error bars represent \pm SD

$\mathrm{dw} \mathrm{m}^{-2}$, respectively. Polychaeta were the dominant taxon, contributing $65 \%$ to total individual numbers and $68 \%$ to total macrofauna biomass. Cirratulidae were the most abundant polychaete family, and Tanaidacea the most important group of Crustacea. The relative abundance and biomass of different families and taxa of Polychaeta and Crustacea are given in Fig. 2. The vertical distribution of macrofaunal organisms and corresponding biomass is given in Fig. 3. The Sognefjord is populated by a deep-dwelling macrofaunal community: almost $50 \%$ of biomass was encountered below $5 \mathrm{~cm}$ sediment depth. Background ${ }^{13} \mathrm{C}$ signatures of macrofauna organisms varied between $\delta^{13} \mathrm{C}=$ $-20.7 \%$ o (Paraonidae, Maldanidae) and $\delta^{13} \mathrm{C}=-16.5 \%$ (gastropods).

Macrofauna organisms rapidly incorporated the ${ }^{13} \mathrm{C}$-labeled substrate. After $8 \mathrm{~h}, 67 \%$ of the organisms had $\delta^{13} \mathrm{C}$ signatures indicative of labeled diatom ingestion. Mean $\Delta \delta^{13} \mathrm{C}$ was $+20 \%$ o $(\mathrm{n}=24)$, but naturally varied greatly between, for example, a very heavily labeled cirratulid polychaete $\left(\Delta \delta^{13} \mathrm{C}=+533 \%\right.$ o $)$ and only slightly labeled sipunculids $\left(\Delta \delta^{13} \mathrm{C}=+8 \%\right.$ o). After $1.5 \mathrm{~d}, 81 \%$ of the individuals were enriched in ${ }^{13} \mathrm{C}$, and mean labeling had risen to $588 \%$ o $\left(n=32, \max . \Delta \delta^{13} \mathrm{C}=\right.$ $+988 \%$ ). After $3 \mathrm{~d}$, the $\delta^{13} \mathrm{C}$ signature of all macrofauna organisms found demonstrated that they had ingested labeled diatom phytodetritus, with $\Delta \delta^{13} \mathrm{C}_{\text {mean }}=$ $+1323 \%$ ( $\mathrm{n}=7$, max. $\Delta \delta^{13} \mathrm{C}=+8115 \%$ ). Thus, within only $3 \mathrm{~d}$, even all the deep-dwelling organisms had accessed the phytodetritus added to the sediment surface.

As shown in Fig. 4, polychaetes dominate the uptake of label: they are the first to access the phytodetritus and continue to assemble tracer throughout the experiments, while the tracer signature is already leveling off again in other metazoa-possibly indicating either that the latter did not feed repeatedly on the fresh organic material or that gut residence time in these groups is much shorter than in the polychaetes. The vertical distribution of $\Delta \delta^{13} \mathrm{C}$ within macrofauna clearly demonstrates that most of the label is incorporated by organisms living close to the sediment surface. However, the heavy labeling of organisms below $5 \mathrm{~cm}$ sediment depth indicates a very fast vertical entrainment of the fresh organic material into the sediment (Fig. 5).

\section{Bacteria}

Total microbial biomass in Sognefjord sediments was $8.5 \pm 1.5 \mathrm{~g} \mathrm{C} \mathrm{m}^{-2}(0-10 \mathrm{~cm})$, with $2.4 \pm 0.3 \mathrm{~g} \mathrm{C} \mathrm{m}^{-2}$ in the upper $2 \mathrm{~cm}$ sediment and $3.6 \pm 0.8 \mathrm{~g} \mathrm{C} \mathrm{m}^{-2}$ between 5 and $10 \mathrm{~cm}$ sediment depth. The enrichment with fresh POM inside the benthic chambers did not result in a significant increase in the total microbial biomass within the experiment duration (Fig. 6). However, an incorporation of label ${ }^{13} \mathrm{C}$ into bacterial fatty acids is

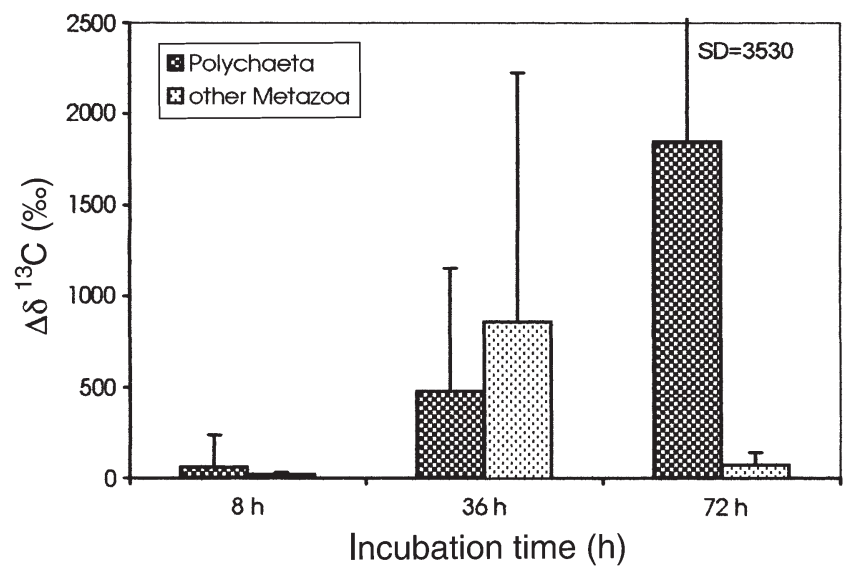

Fig. 4. Excess ${ }^{13} \mathrm{C}$ of polychaetes and other macrofauna during the course of the experiments. Error bars represent $+\mathrm{SD}$ 

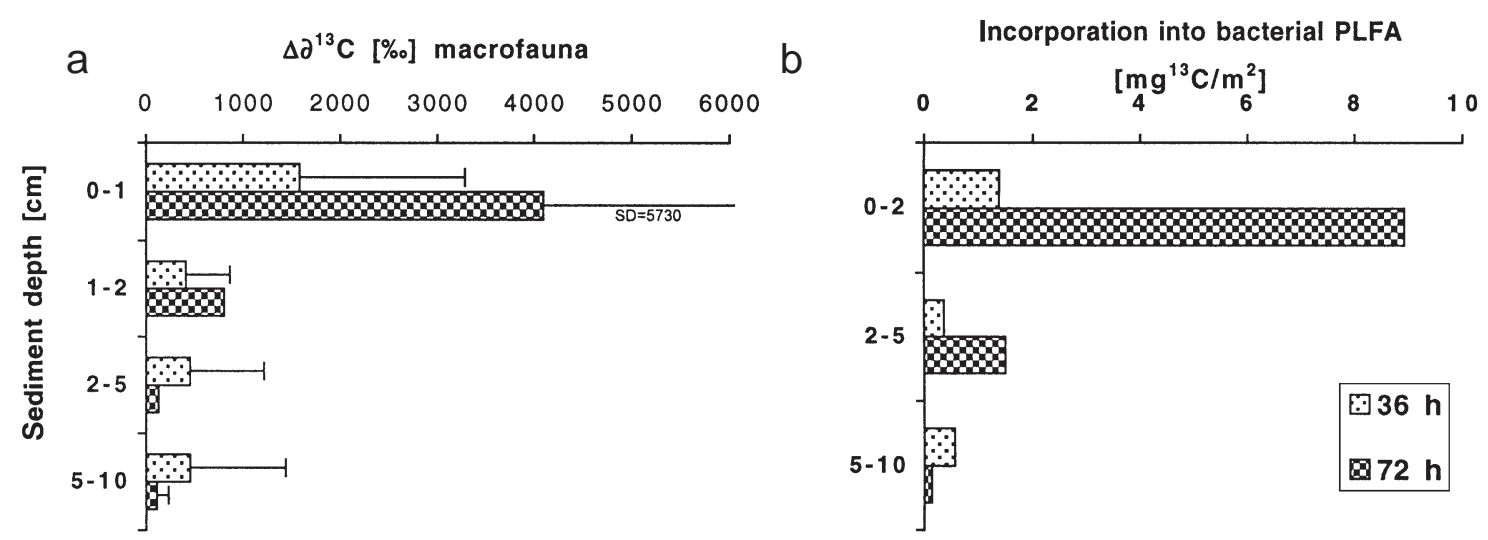

Fig. 5. Vertical distribution (a) of ${ }^{13} \mathrm{C}$ isotopic signatures of macrofauna and (b) of the incorporation of label ${ }^{13} \mathrm{C}$ into bacterial phospholipid-derived fatty acids (PLFA) within the sediment

clearly visible (Fig. 5). As is to be expected, most of this incorporation took place in the uppermost sediment layer. However, some label has also been incorporated by bacteria living below $5 \mathrm{~cm}$ sediment depth, highlighting the fast and effective vertical transport of the material-most likely due to macrofauna activity.

\section{DISCUSSION}

Although it is a unique setting with a distinct topography and hydrography, the Sognefjord is populated by a typical bathyal benthic community (Brattegard 1979). A photographic survey revealed a megafauna community typical of mid-slope depth and the presence of characteristic Lebensspuren and burrow systems (Christiansen 1993). The abundance of macrofauna underlines the comparability of the deep Sognefjord benthic community with sediment commu-

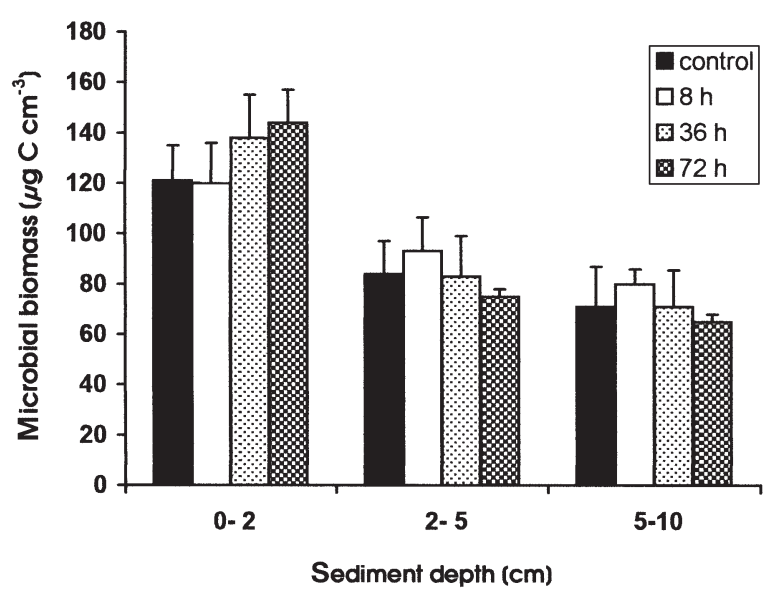

Fig. 6. Changes in total microbial biomass (phospholipid [PL] biomass) in different sediment layers due to POM enrichment. Error bars represent $+\mathrm{SD}$ nities at continental margins. Within the OMEX project, Flach \& Heip (1996) found similar macrofaunal abundance and biomass of 2700 ind. $\mathrm{m}^{-2}$ and 200 to $300 \mathrm{mg}$ organic $\mathrm{C} \mathrm{m}^{-2}$ at 1100 to $1400 \mathrm{~m}$ depth at the Goban Spur continental margin; both macrofaunal abundance and biomass in the Sognefjord fall well within the regressions published in this paper for the NE Atlantic. This also holds true for the contrasting vertical trends of macrofauna abundance and biomass: as in the OMEX area, mean individual biomass increases with sediment depth, i.e. the surface layer is colonized by a large number of smaller individuals, whereas deeper sediment layers are colonized by fewer, but larger individuals. The mid-slope OMEX stations referred to are situated in areas of enhanced organic carbon content of the sediment (Lohse et al. 1998). OPD at the OMEX Stns B (1000 m) and II $(1400 \mathrm{~m})$ were 20 and $30 \mathrm{~mm}$, respectively-comparable to our Sognefjord data. Benthic oxygen uptake at these 2 stations was approximately $3 \mathrm{mmol} \mathrm{O} \mathrm{m}^{-2} \mathrm{~d}^{-1}$ (Lohse et al. 1998). Evidence for an elevated organic carbon content of the sediment at mid-slope depth was also found during the SEEP II study on the NW Atlantic continental margin. Concurrently, high levels of SCOC were encountered that reached maxima of up to $5.8 \mathrm{mmol} \mathrm{O}_{2} \mathrm{~m}^{-2} \mathrm{~d}^{-1}$ at $1000 \mathrm{~m}$ water depth (Rowe et al. 1991). For the Voering plateau (Norwegian continental margin, $1400 \mathrm{~m}$ ) Sauter et al. (2001) gave oxygen uptake rates of $3.08 \mathrm{mmol} \mathrm{O}_{2} \mathrm{~m}^{-2} \mathrm{~d}^{-1}$. These carbon remineralization rates from NE and NW Atlantic continental slope studies compare well with our Sognefjord background $\mathrm{BCR}$ rates of $3.6 \mathrm{mmol} \mathrm{O}_{2} \mathrm{~m}^{-2} \mathrm{~d}^{-1}$. We therefore assume that the results of this study are representative for many mid-slope continental margin sediments.

Smith \& Baldwin (1984) and Smith (1987) were the first to provide evidence for a temporal variation of SCOC in deep-sea sediments, reporting a 2 -fold 
increase in SCOC between February and June for the oligotrophic North Pacific. For the abyssal NE Atlantic, Pfannkuche (1993) documented a significant increase in SCOC in response to a sedimentation event but reported a time lag of several weeks. Witbaard et al. (2000), on the other hand, could not detect an effect of the different quality and quantity of settling phytodetritus on SCOC via in situ respirometry. In a study on the Norwegian continental slope (1400 m) Graf (1989) also reported a considerable time lag between the sedimentation event and a significant enhancement of SCOC. These results are corroborated by our in situ experiments, which reveal a moderate but almost instantaneous increase in SCOC within a few days. All 3 earlier studies were attempts to follow the benthic response to a natural sedimentation event. As it is known from time-lapse camera deployments, phytodetritus settles neither homogeneously nor 'once forever' on the sea floor. On the contrary, it is constantly resuspended and deposited, and it is therefore impossible to unravel the recent depositional history of the very spot on the sea floor where SCOC measurements are taken. In addition, it is not known how long such a response may last. Thus, data on vertical particle flux are very difficult to relate to SCOC measurements, and a possibly rapid but short-term increase in SCOC may easily be missed. An enrichment experiment carried out by Moodley et al. (2002) at $2150 \mathrm{~m}$ depth in the North Atlantic supports our finding of a much faster increase in total BCR rates: in this deep-sea setting, SCOC doubled within $36 \mathrm{~h}$ due to POM enrichment.

The vertical distribution of macrofauna within the sediment in the Sognefjord is unusual with respect to the somewhat larger number of individuals found below $5 \mathrm{~cm}$ sediment depth. Jumars et al. (1990) discussed the relationship between food input and the vertical distribution of macrofauna, and they pointed out that when food is scarce and arrives episodically it is of advantage to sequester as much food as fast as possible and store it out of reach of competitors-i.e. beneath the sediment surface, where most organisms are concentrated. Thus, it can be speculated that the highly episodical food input in northern latitudes causes a larger proportion of the organisms to live deep in the sediment. The proposition of Jumars et al. is strengthened by the rapid subduction of organic matter into deep sediment layers that we observed in the fjord system: within only $3 \mathrm{~d}$, the material had not only reached a sediment depth of 5 to $10 \mathrm{~cm}$ but had also been incorporated into bacterial PLFA, i.e. into bacterial biomass. Graf (1989) also reported the rapid subduction of chlorophyll-rich fecal pellets by sipunculans at the Vøring plateau (Norwegian continental margin, $1400 \mathrm{~m}$ ). Levin et al. (1997) reported a similarly rapid downward transport of fresh phytodetritus at $850 \mathrm{~m}$ on the North Carolina continental slope. Here, deep-dwelling meiofauna in the vicinity of maldanid burrows showed extensive ${ }^{13} \mathrm{C}$ enrichment after $1.5 \mathrm{~d}$. As the $\delta^{13} \mathrm{C}$ signatures of meiofauna organisms cannot discriminate between the uptake of material into the animal's gut system and the true incorporation of the material into body tissue, subduction of the labeled phytodetritus carbon must have been at least as rapid in the deep Sognefjord in order to allow bacteria to incorporate the material. Levin et al. (1997) proposed that the rapid subduction of fresh organic matter that provides other deep-dwelling deposit feeders with highly labile food is a keystone function in deep-sea ecosystems, carried out here by maldanid polychaetes. In the deep Sognefjord, maldanids comprised only $2 \%$ of total polychaetes, and maldanid abundance reached less than $10 \%$ of the abundance of maldanids at the Cape Hatteras study site. In our study area, $70 \%$ of the polychaetes belonged to the family Cirratulidae. Cirratulids, however, are thought to be surface-deposit-feeding, sessile or mobile animals that do not exhibit pronounced deep burrowing activities (Fauchald \& Jumars 1979). This view is supported by the high $\delta^{13} \mathrm{C}$ signatures of cirratulids encountered in the surface layer as opposed to generally low $\delta^{13} \mathrm{C}$ signatures of cirratulids found below $5 \mathrm{~cm}$. Thus, cirratulids are unlikely to have caused the rapid vertical POM transport. In the 5 to $10 \mathrm{~cm}$ layer, high $\delta^{13} \mathrm{C}$ signatures were found for Opheliidae, Maldanidae and some unidentified polychaetes. The burrowing lifestyle of both families is well known (e.g. Fauchald \& Jumars 1979, Levin et al. 1999), and we suggest that despite their scarcity in absolute numbers, these animals are responsible for the rapid vertical mixing we encountered. However, it has to be kept in mind that our experiments might underestimate the actual downward mixing rates of POM in the Sognefjord, because large, deep-living infaunal organisms such as echiurans, which live below $10 \mathrm{~cm}$ sediment depth, are not sampled by the lander chambers. In the southern Arabian Sea, where a large number of spoke traces indicated the presence of many surface-feeding, deepliving large worms, ${ }^{234} \mathrm{Th}$ - and ${ }^{210} \mathrm{~Pb}$-derived bioturbation coefficients were significantly correlated with the abundance of the characteristic spoke-like feeding traces of these organisms (Turnewitsch et al. 2000), but not with macrofaunal colonization patterns.

As they usually dominate benthic biomass in deepsea sediments (e.g. Rowe et al. 1991, Boetius et al. 2000, Turley 2000), bacteria are supposed to be the primary agents of BCR. In the deep Sognefjord, the total microbial biomass (TMB) was $8.5 \mathrm{~g} \mathrm{C} \mathrm{m}^{-2}$, as opposed to a macrofauna biomass of $250 \mathrm{mg} \mathrm{C} \mathrm{m}^{-2}$. Of course the TMB does include microorganisms other than bacteria, but even if we assume that bacteria account for 


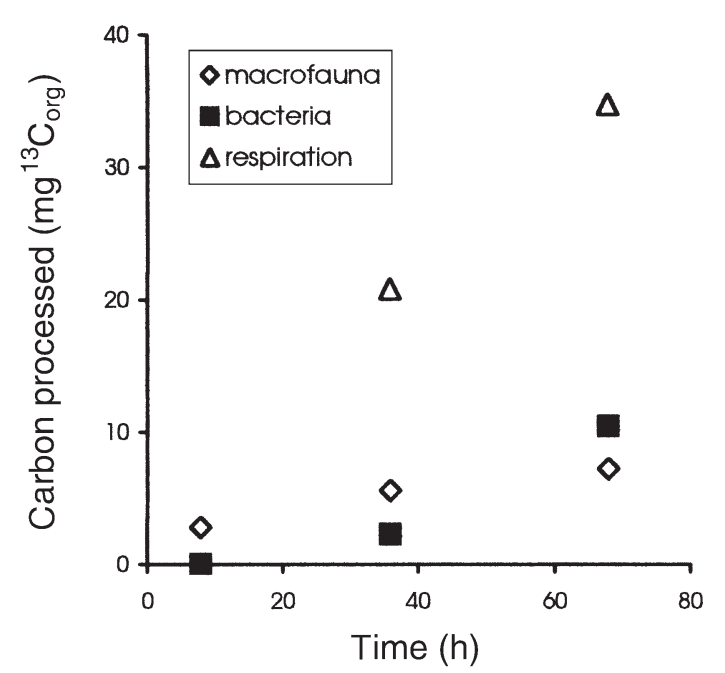

Fig. 7. Pathways of ${ }^{13} \mathrm{C}$ labeled phytodetritus through the benthic community with time: uptake by macrofauna, incorporation by bacteria and loss due to respiration

only $60 \%$ of the TMB (e.g. Schewe 2001 and literature therein), macrofauna still comprise less than $5 \%$ of total benthic biomass. Biomass data for meiofauna are not available, but even if we assume that this equals macrofauna biomass, these groups together still comprise $<10 \%$ of benthic biomass. In the course of the enrichment experiment we could not detect a significant increase in microbial biomass, but it has to be kept in mind that we can only monitor the 'net biomass' of a microbial community that is constantly grazed upon. In any case, the excess ${ }^{13} \mathrm{C}$ found in bacterial PLFA demonstrates the fast uptake of our deliberate tracer by bacteria and proves the capability of microorganisms that live under severe nutrient limitation to react instantaneously to a food pulse. As expected, the majority of the tracer is incorporated by bacteria living close to the sediment surface, but the incorporation of
${ }^{13} \mathrm{C}$ into bacteria below $5 \mathrm{~cm}$ sediment depth demonstrates that microorganisms in deeper sediment layers are also capable of very fast responses to POM and emphasizes the importance of vertical transport of fresh POM mediated by large organisms for biogeochemical cycling in deep-sea sediments.

If we assume that the increase in SCOC due to the POM addition is due to the remineralization of the fresh material added, we can calculate the relative importance of the different benthic compartments as a sink of our carbon tracer: a total amount of $34.75 \mathrm{mg}$ organic ${ }^{13} \mathrm{C}$ was respired within $3 \mathrm{~d}$. Bacteria had incorporated $2.3 \mathrm{mg}$ of ${ }^{13} \mathrm{C}$-labeled diatom carbon after $1.5 \mathrm{~d}$, after $3 \mathrm{~d}$ bacterial incorporation had increased to $10.45 \mathrm{mg}$ organic ${ }^{13} \mathrm{C}$. The tracer uptake by macrofauna rose from $2.8 \mathrm{mg}$ after $8 \mathrm{~h}$ to $7.2 \mathrm{mg}$ after $3 \mathrm{~d}$ (Fig. 7). Thus, despite their low significance in terms of biomass, macrofauna account for $17 \%$ of the material processed (Fig. 8). This implies that a large fraction of the material is passed through the gut system of a larger animal, where its quantity and quality are altered, before it becomes available for other (micro)organisms. This finding is in contrast to the results of Moodley et al. (2002), who carried out a $35 \mathrm{~h}$ enrichment experiment (addition of $0.44 \mathrm{~g} \mathrm{C} \mathrm{m}^{-2}$ ) at $2150 \mathrm{~m}$ depth in the NE Atlantic. At this site, macrofauna biomass was 6 times lower than that in the Sognefjord (approx. $40 \mathrm{mg} \mathrm{C} \mathrm{m}{ }^{-2}$ ). Bacteria and foraminifera were key players in the material turnover, whereas the amount of material taken up by macrofauna was found to be almost negligible $(<5 \%)$. A direct comparison of the 2 studies is hampered by the fact that the work of Moodley et al. (2002) lacks information on the vertical transport of tracer into the sediment, whereas in our study protozoa could not be included. Nevertheless, it can be speculated that the differences are caused by structural and functional differences between the 2 benthic communities and-
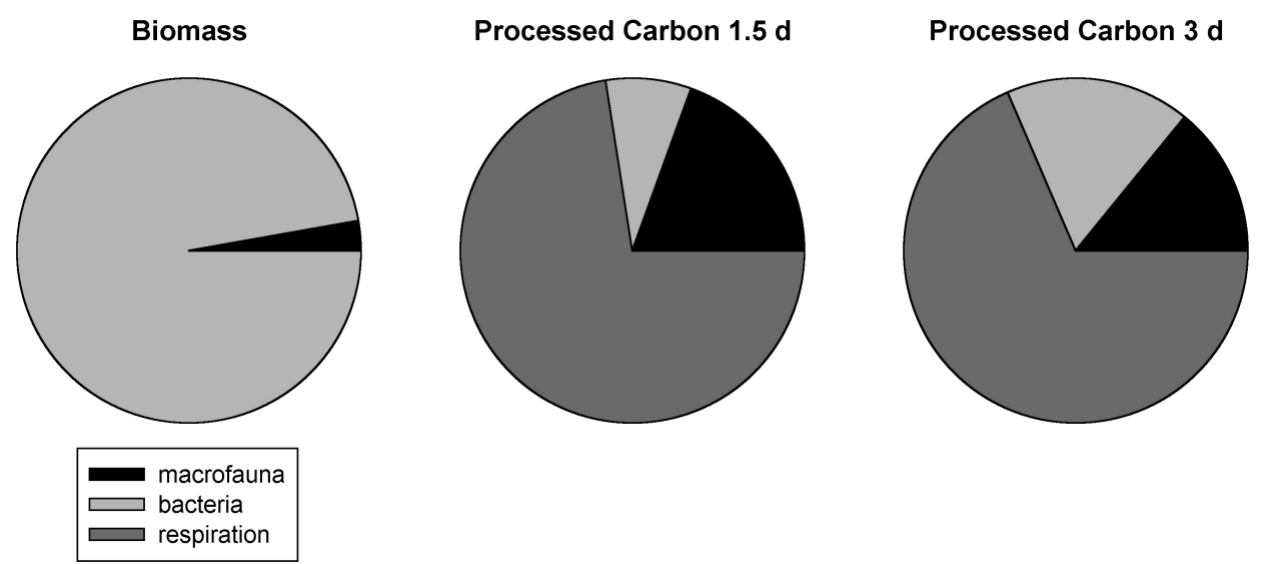

Fig. 8. Proportional division of biomass and processed carbon among the different benthic compartments 
possibly - slope and deep-sea plain communities in general.

In the long run, bacteria clearly outcompete macrofauna in the capacity to process fresh POM, as the bacterial data point to the onset of an exponential increase in tracer incorporation. Altogether, approximately $50 \mathrm{mg} \mathrm{C} \mathrm{m}^{-2}$ or $5 \%$ of the carbon added was processed within $3 \mathrm{~d}$ (or $28.5 \mathrm{mg} \mathrm{C} \mathrm{m}^{-2}$ within $36 \mathrm{~h}$ ) by those benthic compartments examined in this study, i.e. total community respiration, bacteria and macrofauna. The majority of the material was lost due to respiration $(68 \%)$. As bacteria clearly dominate the benthic biomass, bacterial respiration most likely accounts for the majority of the total community respiration. In similar experiments, a deep-sea community at $2150 \mathrm{~m}$ water depth was able to process 6 to $12 \mathrm{mg} \mathrm{C} \mathrm{m}^{-2}$ within $35 \mathrm{~h}$; carbon processing by an intertidal community reached $\sim 61 \mathrm{mg} \mathrm{C} \mathrm{m}{ }^{-2}$ (Moodley et al. 2002). This comparison underlines the functional differences between continental slope and deep-sea sediments and the capability of the former to rapidly process large amounts of organic carbon.

\section{Conclusions}

In the Norwegian Sognefjord we encountered a very rapid reaction of the benthic community to experimental POM enrichment. Within $3 \mathrm{~d}$, SCOC increased by approximately $25 \%$ and macrofauna and bacteria became heavily labeled with ${ }^{13} \mathrm{C}$. The response was not limited to the sediment surface but extended down to at least 5 to $10 \mathrm{~cm}$ sediment depth, most likely due to the activity of opheliid and maldanid polychaetes. Altogether, ca. $50 \mathrm{mg} \mathrm{C} \mathrm{m} \mathrm{C}^{-2}$ were processed within $3 \mathrm{~d}$, the majority being lost due to respiration. Macrofauna processed a surprising $17 \%$ of the material, and we propose that faunal gut systems are important locations for the very first steps of early diagenesis. In terms of sediment biogeochemistry, our Sognefjord station is well comparable to other settings on continental slopes, and we therefore assume that the results of this study are representative for many mid-slope continental margin sediments.

Acknowledgements. Many thanks are due to the captain and crew of RV 'Heincke' for their splendid support at sea and to Axel Cremer, Stefan Meyer and Wolfgang Queisser for technical assistance with the lander systems. W.-D. Abraham from the GBF Braunschweig invited us to his lab and provided invaluable support with the PLFA measurements. Olaf Pfannkuche magnificently coordinated the BIGSET program and provided the chamber lander system for this study. This work was funded by the Bundesministerium für Bildung und Forschung as part of the BIGSET programme (Förderkennzeichen 03F0273A/1).

\section{LITERATURE CITED}

Barnett PRO, Watson J, Connelly D (1984) A multiple corer for taking virtually undisturbed samples from shelf, bathyal and abyssal sediments. Oceanol Acta 7:399-408

Billett DSM, Lampitt RS, Rice AL, Mantoura RFC (1983) Seasonal sedimentation of phytoplankton to the deep-sea benthos. Nature 302:520-522

Blair NE, Levin LA, DeMaster DJ, Plaia G (1996) The shortterm fate of fresh algal carbon in continental slope sediments. Limnol Oceanogr 41:1208-1219

Boetius A, Ferdelmann T, Lochte K (2000) Bacterial activity in sediments of the deep Arabian Sea in relation to vertical flux. Deep-Sea Res II 47:2835-2876

Boschker HTS, de Brouwer JFC, Cappenberg TE (1999) The contribution of macrophyte derived organic matter to microbial biomass in salt-marsh sediments: stable isotope analysis of microbial biomarkers. Limnol Oceanogr 44: 309-319

Brattegard T (1979) Why biologists are interested in fjords. In: Freeland HJ, Farmer DM, Levings CD (eds) Fjord oceanography. Plenum, New York, p 53-66

Brinch-Iversen J, King GM (1990) Effects of substrate concentration, growth state, and oxygen availability on relationships among bacterial carbon, nitrogen and phospholipid phosphorus content. FEMS Microbiol Ecol 74:345-356

Broecker WS, Peng TH (1974) Gas exchange rates between air and sea. Tellus XXVI:21-35

Christiansen B (1993) A television and photographic survey of megafaunal abundance in central Sognefjord, western Norway. Sarsia 78:1-8

Dobbs FC, Findlay RH (1993) Analysis of microbial lipids to determine biomass and detect the response of sedimentary microorganisms to disturbance. In: Kemp PF (ed) Handbook of methods in aquatic microbial ecology. Lewis Publishers, Boca Raton, FL, p 347-358

Drazen JC, Baldwin RJ, Smith KL Jr (1998) Sediment community response to a temporally varying food supply at an abyssal station in the NE Pacific. Deep-Sea Res II 45: 893-913

Fauchald K, Jumars PA (1979) The diet of worms: a study of polychaete feeding guilds. Oceanogr Mar Biol Annu Rev 17:193-284

Findlay RH, King GM, Walting L (1989) Efficacy of phospholipid analysis in determining microbial biomass in sediments. Appl Environ Microbiol 55:2888-2893

Flach E, Heip C (1996) Vertical distribution of macrozoobenthos within the sediment on the continental slope of the Goban Spur area (NE Atlantic). Mar Ecol Prog Ser 141: $55-66$

Fry B (1988) Food web structure on Georges Bank from stable C, N, and S isotopic compositions. Limnol Oceanogr 33: $1182-1190$

Glud RN, Klimant I, Holst G, Kohls O, Kühl M, Gundersen JK (1999) Adaptation, test and in situ measurements with $\mathrm{O}_{2}$ microopt(r)odes on benthic landers. Deep-Sea Res I 46: 171-183

Glud RN, Gundersen JK, Ramsing NB (2000) Electrochemical and optical oxygen microsensors for in situ measurements. In: Buffle J, Hrvai G (eds) In situ monitoring of aquatic systems: chemical analysis and speciation. Wiley, New York, p 19-73

Gooday AJ, Bett BJ, Pratt DN (1993) Direct observation of episodic growth in an abyssal xenophyophore (protista). Deep-Sea Res I 40:2131-2143

Graf G (1989) Benthic-pelagic coupling in a deep-sea benthic community. Nature 341:437-439 
Hecker B (1990) Photographic evidence for the rapid flux of particles to the sea floor and their transport down the continental slope. Deep-Sea Res I 37:1773-1782

Jørgensen BB (1983) Processes at the sediment-water interface. In: Bolin B, Cook RB (eds) The major biogeochemical cycles and their interactions. Wiley, New York, p 477-515

Jumars PA, Mayer LM, Deming JW, Baross JA, Wheatcroft RA (1990) Deep-sea deposit-feeding strategies suggested by environmental and feeding constraints. Phil Trans $\mathrm{R}$ Soc Lond B 331:85-101

Lampitt RS (1985) Evidence for the seasonal deposition of detritus to the deep-sea floor and its subsequent resuspension. Deep-Sea Res I 32:885-897

Lauermann LML, Smoak JM, Shaw TJ, More WS, Smith KL Jr (1997) ${ }^{234} \mathrm{Th}$ and ${ }^{210} \mathrm{~Pb}$ evidence for rapid ingestion of settling particles by mobile epibenthic megafauna in the abyssal NE Pacific. Limnol Oceanogr 42:589-595

Levin LA, Blair NE, DeMaster DJ, Plaia G, Fornes W, Martin C, Thomas C (1997) Rapid subduction of organic matter by maldanid polychaetes on the North Carolina slope. J Mar Res 55:595-611

Levin LA, Blair NE, Martin CM, DeMaster DJ, Plaia G, Thomas CJ (1999) Macrofaunal processing of phytodetritus at two sites on the Carolina margin: in situ experiments using ${ }^{13}$ C-labeled diatoms. Mar Ecol Prog Ser 182:37-54

Li YH, Gregory S (1974) Diffusion of ions in sea water and in deep-sea sediments. Geochim Cosmochim Acta 38: 703-714

Linke P (1992) Metabolic adaptations of deep-sea benthic foraminifera to seasonally varying food input. Mar Ecol Prog Ser 81:51-63

Linke P, Altenbach AV, Graf G, Heeger T (1995) Response of deep-sea benthic foraminifera to a simulated sedimentation event. J Foraminifer Res 25(1):75-82

Lochte K, Turley CM (1988) Bacteria and cyanobacteria associated with phytodetritus in the deep-sea. Nature 333: 67-69

Lohse L, Helder W, Epping EHG, Balzer W (1998) Recycling of organic matter along a shelf-slope transect across the N. W. European Continental Margin (Goban Spur). Prog Oceanogr 42:77-110

Middelburg JJ, Soetart K, Hermann PMJ (1997) Empirical relationships for use in global diagenetic models. DeepSea Res I 44:327-344

Middelburg JJ, Barranguet C, Boschker HTS, Hermann PMJ, Moens T, Heip CHR (2000) The fate of intertidal microphytobenthos carbon: an in situ ${ }^{13} \mathrm{C}$-labeling study. Limnol Oceanogr 45:1224-1234

Moodley L, Middelburg JJ, Boschker HTS, Duineveld GCA, Pel R, Hermann PMJ, Heip CHR (2002) Bacteria and Foraminifera: key players in a short-term deep-sea benthic response to phytodetritus. Mar Ecol Prog Ser 236:23-29

Pfannkuche O (1993) Benthic response to the sedimentation of particulate organic matter at the BIOTRANS station, $47^{\circ} \mathrm{N}, 20^{\circ} \mathrm{W}$. Deep-Sea Res 40:135-149

Pfannkuche O, Boetius A, Lochte $\mathrm{K}$, Lundgreen U, Thiel H (1999) Responses of deep-sea benthos to sedimentation patterns in the North-East Atlantic in 1992. Deep-Sea Res I 46:573-596

Poremba K, Jeskulke K (1995) Microbial activity in the sediment of the Sognefjord (Norway). Helgol Meeresunters 49:169-176

Editorial responsibility: Otto Kinne (Editor),

Oldendorf/Luhe, Germany
Rasmussen H, Jørgensen BB (1992) Microelectrode studies of seasonal oxygen uptake in a coastal sediment: role of molecular diffusion. Mar Ecol Prog Ser 81:289-303

Revsbech NP (1989) An oxygen microsensor with a guard cathode. Limnol Oceanogr 34:474-478

Revsbech NP, Jørgensen BB (1986) Microelectrodes: their use in microbial ecology. In: Marschall KC (ed) Advances in microbial ecology. Plenum, New York, p 293-352

Rowe GT, Sibuet M, Demin JW, Khripounoff A, Tietjen JM, Theroux R (1991) 'Total' sediment biomass and preliminary estimates of organic carbon residence time in deepsea benthos. Mar Ecol Prog Ser 79:99-114

Sauter E, Schlüter M, Suess E (2001) Organic carbon flux and remineralization in surface sediments from the northern North Atlantic derived from pore-water oxygen microprofiles. Deep-Sea Res I 48:529-553

Sayles FL, Martin WR, Deuser WG (1994) Response of benthic oxygen demand to particulate organic carbon supply in the deep sea near Bermuda. Nature 371:686-689

Schewe I (2001) Small-sized benthic organisms of the Alpha Ridge, Central Arctic Ocean. Int Rev Ges Hydrobiol 86: 317-335

Smith KL Jr (1987) Food energy supply and demand: a discrepancy between particulate organic carbon flux and sediment community oxygen consumption in the deep ocean. Limnol Oceanogr 32:201-220

Smith KL Jr, Baldwin RJ (1984) Seasonal fluctuations in deepsea sediment community oxygen consumption: central and eastern north Pacific. Nature 307:624-625

Thiel HO, Pfannkuche O, Schriever G, Lochte K, Gooday AJ and 5 others (1989) Phytodetritus on the deep-sea floor in a central oceanic region of the Northeast Atlantic. Biol Oceanogr 206:303-239

Turley C (2000) Bacteria in the cold deep-sea benthic boundary layer and sediment-water interface of the NE Atlantic. FEMS Microbiol Ecol 33:89-99

Turnewitsch R, Witte U, Graf G (2000) Bioturbation in the deep Arabian Sea: influence of fauna and food supply. Deep-Sea Res II 47:2877-2911

Tyler PA (1988) Seasonality in the deep sea. Oceanogr Mar Biol Annu Rev 26:227-258

Tyler PA, Billet DSM, Gage JD (1990) Seasonal reproduction in the seastar Dytaster grandis from $4000 \mathrm{~m}$ in the northeast Atlantic Ocean. J Mar Biol Assoc UK 70:173-180

Wenzhöfer F, Glud RN (2002) Benthic carbon remineralisation in the Atlantic: a synthesis based on in situ data from the last decade. Deep-Sea Res 49:1255-1279

Wenzhöfer F, Holby O, Kohls O (2001) deep penetrating benthic oxygen profiles measured in situ by oxygen optodes. Deep-Sea Res I 48:1741-1755

Witbaard R, Duineveld GCA, Van der Weele JA, Berghuis EM, Reyss JP (2000) The benthic response to the seasonal deposition of phytopigments at the Porcupine Abyssal Plain in the North East Atlantic. J Sea Res 43:15-31

Witte U (1996) Seasonal reproduction in deep-sea spongestriggered by vertical particle flux? Mar Biol 124:571-581

Witte U (2000) Vertical distribution of macrofauna within the sediment at four sites with contrasting food supply in the deep Arabian Sea. Deep-Sea Res II 47:2979-2997

Witte U, Pfannkuche O (2000) High rates of benthic carbon remineralisation in the abyssal Arabian Sea. Deep-Sea Res II 47:2785-2804

Submitted: May 3, 2002; Accepted: November 19, 2002

Proofs received from author(s): March 11, 2003 